\title{
The Effect of Implementing Interval Method Using Weighted Vest on Power Endurance Abbilities Pusaka Angel's Players
}

Ayi Mohammad Yusupa*, Herdiansyah Agus ${ }^{\mathrm{b}}$, Yunyun Yudiana ${ }^{\mathrm{c}}$, Dikdik Zafar Sidik ${ }^{\mathrm{d}}$

abcdUniversitas Pendidikan Indonesia, Indonesia

Correspondence: ayifutsal02@gmail.com

Received: 28 Aug 2020 Accepted: 16 Des 2020 Published: 30 Apr 2021

\begin{abstract}
Power endurance capability is needed by players to maintain explosivity in a tired state. Both explosivity in running and technical explosivity in the game. To increase the power endurance ability, at the interval of the match after the first week the Pusaka Angel coach team provides training using the interval method accompanied by the use of a weighted vest. The use of the interval method because this method is one of the training methods that can increase the ability of power endurance. The research method is to process the variable data identified from the test results and measurements of the power endurance ability of the women's futsal athletes from the Pusaka Angel team. relationship and the level of relationship made to events that have taken place or have occurred. This was done untreated for 8 weeks. The target population in this study were all female futsal athletes from the Pusaka Angel team. Meanwhile, the affordable population is determined by athletes prepared to participate in the 2019/2020 Indonesian Professional Futsal League, totaling 17 female athletes. Based on data processing and statistical analysis in this study, it can be concluded that there is a significant effect of the application of the interval method using a weighted vest on increasing the power endurance ability of the heirloom futsal players.
\end{abstract}

Keywords: interval training; physical training.; power endurance; training method; weighted vest.

\begin{abstract}
Abstrak
Kemampuan power endurance dibutuhkan oleh pemain untuk mempertahankan explosivitas dalam keadaan lelah. Baik explosivitas dalam berlari maupun explosivitas teknik dalam permainan. Untuk meningkatkan kemampuan power endurance, pada jeda pertandingan setelah pekan pertama tim pelatih Pusaka Angel memberikan latihan dengan metode interval disertai penggunaan rompi beban (weighted vest). Penggunaan metode interval dikarnakan metode tersebut merupakan salah satu metode latihan yang dapat meningkatkan kemampuan power endurance. Metode penelitian yaitu dengan mengolah data variabel yang diidentifikasi dari hasil tes dan pengukuran terhadap kemampuan power endurance atlet futsal putri tim Pusaka Angels yang lalu, data dikumpulkan, dikelompokan untuk dianalisis kemungkinan hubungan antara variabel tersebut, tipe ini merupakan metode penelitian ex-post facto, meneliti hubungan dan tingkat hubungan yang dilakukan terhadap peristiwa yang telah berlangsung atau telah terjadi. Ini dilakukan intervensi selama 8 minggu. Populasi sasaran dalam penelitian ini adalah seluruh atlet futsal putri tim Pusaka Angels. Sedangkan populasi penelitian ditetapkan pada atlet yang dipersiapkan untuk mengikuti Liga Futsal Profesional Indonesia 2019/2020 yang berjumlah 17 atlet putri. Berdasarkan pengolahan data dan analisis statistik pada penelitian ini, dapat disimpulkan bahwa terdapat pengaruh yang signifikan penerapan metode interval dengan menggunakan rompi beban (weighted vest) terhadap peningkatan kemampuan power endurance pemain futsal putri Pusaka Angels.
\end{abstract}

Kata kunci: interval training; latihan fisik; metode latihan; power endurance; rompi beban. 


\section{Pendahuluan}

Futsal adalah pemainan intensitas tinggi dalam waktu 2 × 20 menit yang membutuhkan teknik, fisik dan taktik tingkat tinggi (Naser et al., 2017). Pentingnya daya tahan dan sprint berulang-ulang diperkuat oleh penelitian Ayarra (2018) dan Barbero-Alvarez dkk (2008). Ayarra (2018) mengungkapkan bahwa komponen fisik pembeda dalam tingkatan level-level kompetisi futsal adalah daya tahan dan sprint yang berulang. Semakin tinggi level kompetisinya, semakin tinggi pula level daya tahan dan sprint berulangnya. Paul Ham William (dalam Mulyawan dkk, 2016) mengatakan bahwa "power endurance yaitu melakukan kekuatan dan kecepatan yang berulang-ulang”. Selain itu Mulyawan dkk (2016) juga menjelaskan "Di dalam futsal power yang ada tidak hanya dilakukan untuk satu kali pengulangan tetapi terdiri dari banyak pengulangan. Oleh karena itu, dibutuhkan power endurance untuk menunjang kemampuan seseorang dalam bermain futsal". Sejalan dengan hal tersebut Dikdik Zafar Sidik (dalam John \& Sidik, 2017) menjelaskan "Power endurance sangat penting untuk dilatih karena terjadi pengulangan teknik dasar yang harus mengerahkan kekuatan yang maksimal dalam waktu yang cukup singkat dengan durasi kerja yang lama karena melakukannya secara berulang-ulang pada satu pertandingan". Kemampuan power endurance dibutuhkan oleh pemain untuk mempertahankan explosivitas dalam keadaan lelah. Baik explosivitas dalam berlari maupun explosivitas teknik dalam permainan. Untuk meningkatkan kemampuan power endurance, pada jeda pertandingan setelah pekan pertama kompetisi, tim pelatih Pusaka Angel memberikan latihan dengan metode interval disertai penggunaan rompi beban (weighted vest) dalam latihannya. Metode interval digunakan karena metode tersebut merupakan salah satu metode latihan yang dapat meningkatkan kemampuan power endurance.

Secara garis besar metode latihan interval dalam beberapa penelitian terbagi menjadi HIIT (bigh-intensity interval training) dan SIT (sprint interval training) (Cicioni-kolsky dkk., 2013; MacInnis \& Gibala, 2017; Buchheit \& Laursen, 2013). High-intensity interval training merupakan metode latihan yang efisien untuk meningkatkan cardiorespiratory dan fungsi metabolic, yang tentunya meningkatkan performa fisik atlet. "High-intensity interval training (HIT) is a well-known, time-effecient training method for improving cardiorespiratory and metabolic fungtion and, in turn, physical performace athletes" (Buchheit \& Laursen, 2013). Kemudian Buchheit \& Laursen juga menjelaskan bahwa High-intensity intervl training (HIT) dilakukan dengan latihan pendek (kurang dari 45 detik) sampai panjang ( 2 sampai 4 menit) dengan usaha atau intensitas yang tinggi, namun tidak sampai maksimal. Bentuk-bentuk latihan ini dikombinasikan untuk membuat sesi latihan yang berlangsung antara 5 sampai 40 menit, termasuk di dalamnya periode-periode istirahat.

Bolger dkk (2016) dalam penelitiannya yang mengeksplorasi pelatih-pelatih sprinter dunia (ahli) tentang latihan dengan beban tambahan (resistance-based training) yang berjudul "Coaching sprinting: Expert coaches' perception of resistance-based training". Pada penelitian tersebut Bolger dkk menemukan bahwa pada umumnya bentuk latihan terbagi menjadi 3, yaitu resistance-based training, resisted running dan plyometrics "The most prevalent exercises used by these seven coaches are split into the following three categories: RT, resisted running, and plyometrics" (Bolger dkk, 2016). Dari berbagai macam peralatan yang digunakan dalam latihan resisted training tersebut, Bolger (2016) menyatakan bahwa jaket beban dan lari ditanjakanlah adalah bentuk latihan yang paling banyak digunakan. "Weighted jacket' and 'bill running' were amongst the most commonly used form of Resisted running Along with 'weighted sleds/tires' and 'bungee cords"' (Bolger dkk., 2016). Dari kedua jenis atau bentuk latihan yang paling banyak digunakan tersebut (Weighted jacket and hill running), jaket beban atau rompi beban (weighted vest) menjadi peralatan yang paling realistis untuk digunakan sebagai beban tambahan pada latihan cabang olahraga futsal. Karena olahraga futsal adalah olahraga yang sangat dinamis pada bentuk dan arah gerakan-gerakannya. Sehingga membutuhkan peralatan latihan yang tidak menghambat bentuk dan arah pergerakan atlet dalam permainan futsal. Berdasarkan penjelasan di atas, untuk memenuhi kebutuhan atlet futsal putri Pusaka akan kemampuan power endurance, tim pelatih memberikan latihan dengan metode interval disertai penggunaan rompi beban (weighted vest) untuk meningkatkan kemampuan power endurance atlet futsal Pusaka Angel. 


\section{Metode Penelitian}

Penelitian ini bertujuan untuk mencari kebenaran dalam sebuah pengaruh metode latihan interval training dengan menggunakan rompi beban (weighted vest) dikaitkan dengan power endurance melalui metode ilmiah. Metode penelitian yang digunakan dalam penelitian ini adalah dengan menggunakan metode ex-post facto. Sedangkan desain penelitian yang digunakan adalah one-group pretest-posttest design. Dalam desain ini terdapat satu group yang diberikan perlakukan, serta dilakukan tes sebelum dan sesudah perlakuan diberikan, untuk melihat dampak dari perlakuan tersebut.

Perlakuan pelatihan metode interval training menggunakan rompi beban (weighted vest) yang diberikan kepada atlet saat periodisasi latihan berlangsung pada masa Persiapan khusus dan pra kompetisi, dengan ketentuan atlet telah memiliki usia latihan yang cukup, kondisi fisik dasar yang memadai (terutama strength, power, dan daya tahan cardiovascular). Perlakuan dilaksanakan pada tahap persiapan khusus selama selama 8 minggu, yang sebelumnya didahului dengan strength training pada fase sebelumnya, berupa anatomical adaptation dan maximal strength, adanya fase latihan strength yang mendahului dilakukan agar atlet benar-benar memiliki tingkat kekuatan yang baik. Ketika menerapkan latihan dengan metode interval training menggunakan rompi beban (weighted vest) pelatih mempertimbangkan beberapa faktor, diantaranya: usia kronologis, usia latihan, riwayat latihan, kondisi fisik dasar yang memadai (terutama strength, power, dan daya tahan cardiovascular), pemilihan latihan, beban, dan respons masing-masing atlet terhadap latihan interval dengan menggunakan rompi beban (weighted vest).

Populasi dari penelitian ini adalah 17 orang atlet tim futsal putri Pusaka Angel. Usia atlet berkisar antara 19 sampai 29 tahun. Dengan berat antara 44 sampai 60 kilogram. Rata-rata berat badan sampel adalah 42,1 kilogram. Sedangkan tinggi antara 152 sampai 168 sentimeter. Rata-rata tinggi sampel adalah 160,1 sentimeter.

Teknik pengambilan sampel menggunakan teknik total sampling. Sehingga seluruh atlet tim Pusaka Angels sebanyak 17 orang menjadi sampel pada penelitian ini. Pada tes awal dan pemberian perlakuan, seluruh atlet berpartisipasi, namun pada saat tes akhir, karena beberapa alasan tertentu, 4 orarng pemain tidak dapat mengikuti tes akhir. Sehingga pada saat pengolahan data, hanya ada 13 data atlet yang dianalisis $(76 \%)$.

Pengambilan data dilakukan menggunakan instrumen tes yaitu multi stage burdle jump test. Pre test dan post test pada sampel dilakukan di FPOK UPI kampus Padasuka. Tes dilakukan setelah atlet melakukan pemanasan, dan dilakukan sebelum melakukan aktivitas latihan berat lainnya. Data yang dihasilkan dari pre test dan post test adalah data berbentuk rasio. Untuk menguji efek dari pemberian latihan interval dengan menggunakan rompi beban, dilakukan uji perbedaan dua rata-rata sampel berpasangan antara pretest dan posttest dengan menggunakan analisis statistik uji $\mathrm{T}$ sampel berpasangan yang sebelumnya ada pengujian data distribusi normal dianalisis dengan uji Shapiro-Wilk. Hasil pengujian kemampuan power endurance. Tingkat kekeliruan ditetapkan pada $\alpha=0,05$.

Bolger dkk (2016) dalam penelitiannya yang mengeksplorasi pelatih-pelatih sprinter dunia (ahli) tentang latihan dengan beban tambahan (resistance-based training) yang berjudul "Coaching sprinting: Expert coaches' perception of resistance-based training". Pada penelitian tersebut Bolger dkk menemukan bahwa pada umumnya bentuk latihan terbagi menjadi 3, yaitu resistance-based training, resisted running dan plyometrics "The most prevalent exercises used by these seven coaches are split into the following three categories: RT, resisted running, and plyometrics" (Bolger dkk, 2016). Pada penelitian ini membandingkan kemampuan atlet pada tes awal dan tes akhir. Apakah perbedaan kemampuan atlet pada tes awal dan tes akhir berbeda secara signifikan hasil dari latihan yang diberikan? 
Untuk menjawab pertanyaan dalam penelitian ini, digunkan Uji T sampel berpasangan untuk menguji hiptesis yang diajukan. Setiap sampel yang memiliki data berpasangan, yaitu data tes awal kemampuan power endurance dan data tes akhir kemampuan power endurance akan dibandingkan, dan dianalisis peningkatannya. Sebelum dilakukan pengujian hipotesis, terlebih dahulu dilakukan uji normalitas data menggunakan uji Shapiro-wilk untuk melihat apakah data yang dikumpulkan berdistribusi normal atau tidak. Sebagai acuan untuk menentukan teknik pengujian hipotesis. Analisis data dibantu dengan aplikasi SPSS 24.

\section{Hasil}

Penelitian ini dilaksanakan selama delapan minggu dengan tiga sesi latihan perminggunya, sehingga total ada 24 sesi latihan. Usia atlet yang menjadi sampel penelitian berkisar antara 19 sampai 29 tahun. Dengan berat antara 44 sampai 60 kilogram. Rata-rata berat badan sampel adalah 42,1 kilogram. Sedangkan tinggi antara 152 sampai 168 sentimeter. Rata-rata tinggi sampel adalah 160,1 sentimeter. Variabel terikat pada penelitian ini adalah kemampuan power endurance. Data kemampuan power endurance diperoleh dengan melakukan tes multi stage budle jump test. Data tersebut dideskripsikan melalui tabel di bawah ini:

Tabel 1. Data Hasil Penelitian

\begin{tabular}{ccccc}
\hline Data & Min & Max & Mean & Std. Deviasi \\
\hline Tes awal & 77 & 104 & 89,62 & 8,91 \\
\hline Tes akhir & 76 & 132 & 108,85 & 15,39 \\
\hline
\end{tabular}

Hasil analisis data memperlihatkan bahwa pada tes awal nilai terendahnya adalah 77 nilai tertinggi 104 dengan rata-rata kemampuan power endurancenya adalah 89,62 dan standar deviasinya 8,91. Sedangkan pada tes akhir terdapat nilai terendahnya 76 nilai tertinggi 132 dengan rata-rata kemampuan power endurancenya adalah 108,85 dan standar deviasinya 15,39.

Berdasarkan deskripsi data pada tabel diatas, terlihat bahwa kemampuan power endurance atlet yang telah diberikan latihan metode interval dengan meggunakan rompi beban memiliki perbedaan dalam hasil tes awal dan tes akhirnya. Berdasarkan perbandingan tersebut terlihat peningkatan kemampuan power endurance.

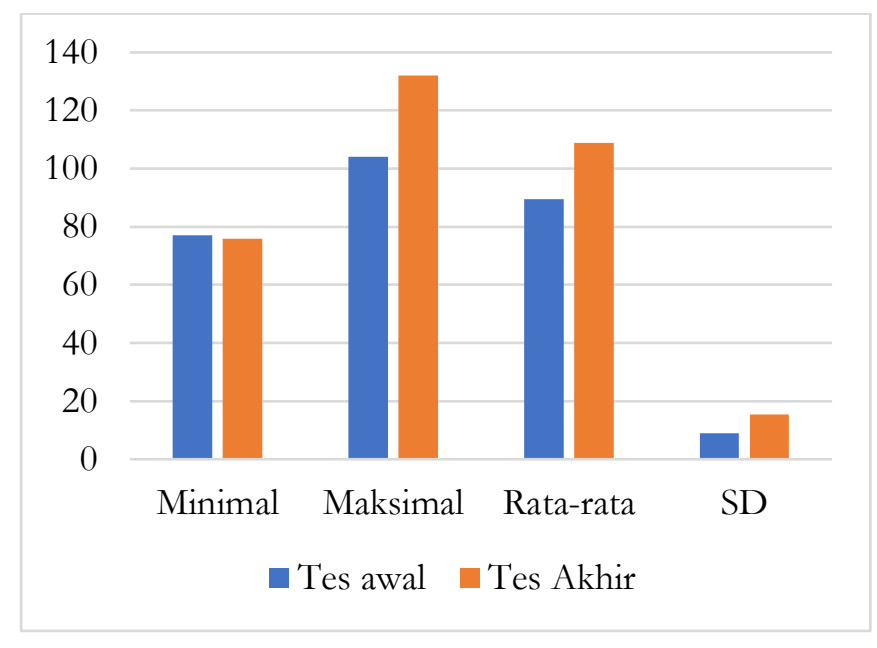

Gambar 1. Perbandingan tes awal dan tes akhir 
Berdasakan gambar di atas terlihat bahwa terjadi peningkatan rata-rata kemampuan power endurace atlet futsal putri Pusaka Angel. Pada tes awal rata-rata kemampuan power endurance atlet memiliki nilai 89,2. Sedangkan pada tes akhir kemampuan power endurance atlet memiliki nilai 108,85.

Untuk menguji hipotesis penelitian, terlebih dahulu dilakukan tes prasyarat yaitu tes normalitas. Pada penelitian ini tes normalitas menggunakan tes shapiro wilk dengaan bantuan aplikasi SPSS 24. Data dikatakan normal apabila memiliki nilai signifikansi besar dari 0,05 (sig. $>0.05$ ), sebaliknya apabila nilai signifikasi kecil dari 0.05 (sig. < 0.05) maka data dinyatakan tidak normal. Pada penelitian ini hasil tes normalitas menunjukkan nilai signifikansi sebesar 0.623. Dari hasil tersebut dapat disimpulkan bahwa data yang diambil berdistribusi normal.

Untuk menguji hipotesis digunakan teknik analisis data uji-Tsampel berpasangan. Tes ini menganalisis perbedaan rata-rata dua kelompok data yaitu kelompok data tes awal dan kelompok data tes akhir.

Tabel 2. Hasil Uji T Sampel Berpasangan

\begin{tabular}{llllll}
\hline & Mean & Stdv & T & df & Sig. (2-tailed) \\
\hline $\begin{array}{l}\text { Tes awal - } \\
\text { Tes Akhir }\end{array}$ & -19.23 & 12.54 & -5.530 & 12 & 0.000 \\
\hline
\end{tabular}

Berdasarkan tabel diatas, hasil analisis data memperlihatkan nilai sig. (2-tailed) adalah 0.000. yang artinya nilai sig. $<0.05$. Nilai sig. yang lebih kecil dari 0.05 memperlihatkan pengaruh yang signifikan dari perlakuan latihan interval dengan menggunakan rompi beban (weighted vest) terhadap peningkatan kemampuan power endurance atlet futsal putri Pusaka Angels.

\section{Pembahasan}

Power endurance adalah hubungan antara power dan waktu (power-duration) atau dengan kata lain, power yang dipertahankan dalam waktu tertentu (Poole dkk., 1990). Futsal membutuhkan power endurance untuk melakukan teknik dasar yang harus mengerahkan kekuatan yang maksimal dalam waktu yang cukup singkat dan melakukannya secara berulang-ulang pada satu pertandingan (Rodrígue-Lorenzo, 2016). Selain itu futsal membutuhkan power endurance untuk melakukan sprint pendek yang berulangulang, yang dilakukan dalam satu pertandingan (Dogramaci dkk, 2011), bahkan semakin tinggi kompetisi yang diikuti, semakin tinggi pula kebutuhan akan pengulangan-pengulangan sprint tersebut dalam sebuah pertandingan (Mohammed dkk., 2014).

Program latihan yang diberikan selama delapan minggu kepada atlet futsal putri Pusaka Angel, selain menggunakan metode interval training, juga digunakan rompi beban (weighted vest) untuk menambah efek loading dalam latihan interval tersebut. Penambahan beban latihan menggunakan rompi beban termasuk pada salah satu bentuk latihan resisted training. Menambah tahanan atau beban (berat) ketika atlet melakukan aktivitas latihan. Secara umum tujuan dari resisted training adalah untuk meningkatkan power otot pada tubuh bagian bawah sambil mempertahankan teknik berlari (Cottle et al., 2014; Cronin \& Hansen, 2006). Penggunaan rompi beban sangat dianjurkan dalam latihan dengan bentuk gerakannya berlari, melompat, dan gerakan-gerakan eksplosif lainnya tanpa membatasi ruang gerak atlet (Clark et al., 2010; Cottle et al., 2014; Bolger et al., 2016; Cronin \& Hansen, 2006; Harrison \& Bourke, 2009). Latihan resisted training menggunakan rompi beban terbukti dapat meningkatkan akselerasi (BacheroMena \& Gonzalez-Badillo, 2014), Melalui analisis data dan pengujian hipotesis yang telah dilakukan sebelumnya, disimpulkan bahwa untuk meningkatkan kemampuan power endurance pemain futsal putri pusaka dapat dilakukan dengan pelatihan metode interval menggunakan rompi beban (weighted vest), dan peningkatan power endurance pemain futsal putri pusaka ini telah terbukti signifikan dengan pemberian latihan selama 8 minggu, yang dilakukan dalam jeda pertadningan tim Pusaka Angel dalam mengarungi kompetisi Woman Professional Futsal League 2019/2020. 


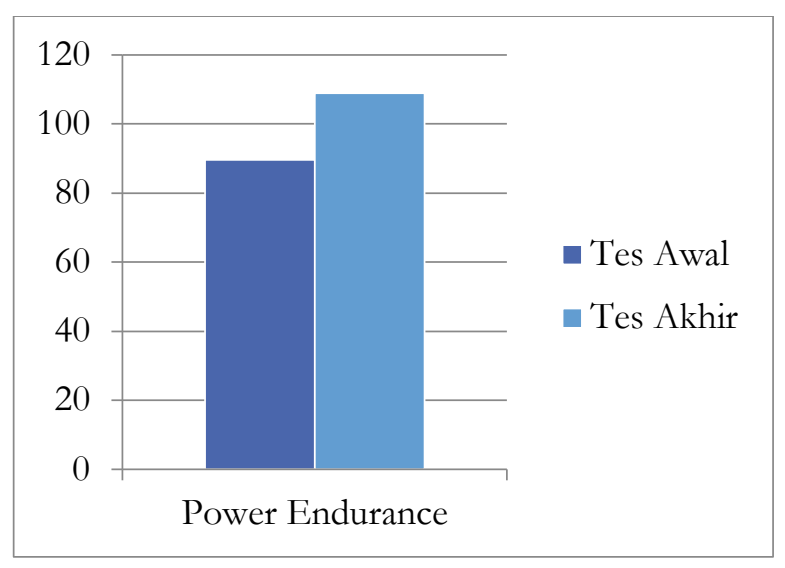

\section{Gambar 3. Grafik Rata-Rata Tes Awal dan Tes Akhir}

Pada gambar grafik di atas terlihat perbedaan rata-rata kemampuan power endurance atlet tim Pusaka Angel sebelum dan sesudah mendapatkan latihan metode interval menggunakan rompi beban (weighted vest). Pada gambar tersebut juga dapat terlihat bahwa rata-rata rata-rata kemampuan power endurance atlet tim Pusaka Angel sesudah mendapatkan latihan metode interval menggunakan rompi beban (weighted vest) lebih tinggi daripada sebelum medapatkan treatment latihan. Dan perbedaan tersebut telah dibuktikan signifikan setelah dilakukan uji statistik yang telah dijelaskan sebelumnya.

Untuk melihat lebih jelas tentang peningkatan power endurance atlet tim Pusaka Angel, berikut penulis sertakan grafik rata-rata data kemampuan power endurance atlet yang dites menggunakan item tes multistage hurdle jump test pada detik ke dua puluh, empat puluh, dan enam puluh.

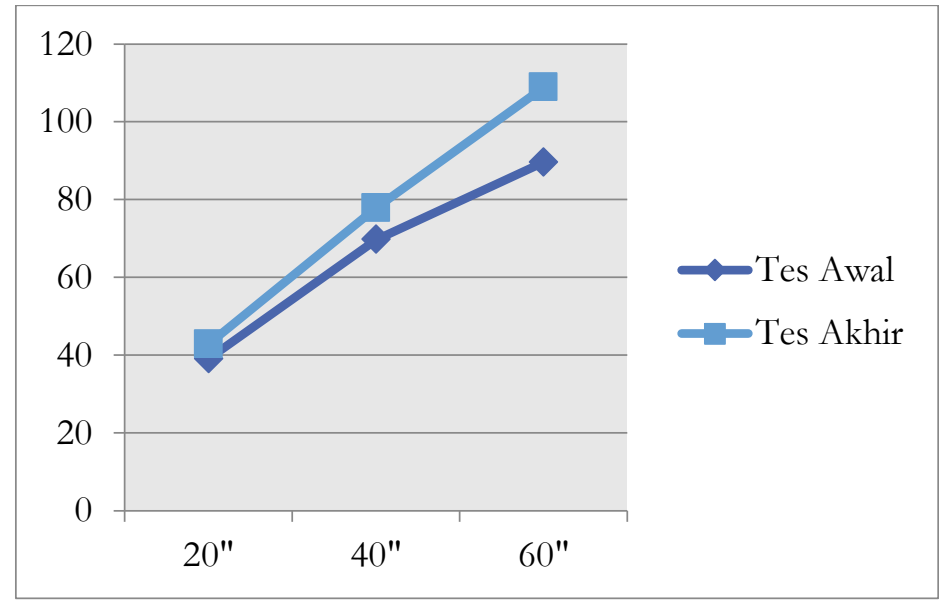

Gambar 4. Grafik Rata-Rata Kemampuan Power Endurance 
Pada grafik di atas, terlihat perbedaan rata-rata kemampuan power endurance atlet pada saaat sebelum dan sesudah mendapatkan latihan metode interval menggunakan rompi beban (weighted vest). Berdasarkan grafik di atas juga dapat diketahui bukan hanya perbedaaan, tapi juga terdapat peningkatan kemampuan, baik pada data kemampuan power endurance 20 detik, 40 detik, maupun 60 detik.

Berdasarkan grafik diatas tersebut juga dapat diamati bahwa kemampuan power endurance atlet Pusaka Angel pada saat sebelum mendapatkan latihan metode interval menggunakan rompi beban (weighted vest), mengalami penurunan kemapuan pada detik ke 40, dan semakin menurun pada detik ke 60 . Yang artinya kemampuan atlet untuk mempertahankan powernya tidak baik. Berbeda dengan kemampuan power endurance atlet Pusaka Angel pada saat sesudah mendapatkan treatment. Secara umum terlihat atlet mampu mempertahankan kemampuan power endurancenya. Ini terlihat pada grafik kemampuan atlet pada detik ke 20, 40, dan 60 tidak terjadi penurunan yang terlalu drastis. Bahkan rata-rata atlet dapat mempertahankan kemampuan powernya secara konstan. Ini menandakan bahwa kemampuan atlet untuk melawan kelelahan dan mempertahankan powernya semakin baik. Artinya hasil penelitian yang menunjukkan bahwa terdapat pengaruh yang signifikan latihan metode interval menggunakan rompi beban (weighted vest) terhadap power endurance dapat dibuktikan.

Pengaruh metode interval menggunakan rompi beban (weighted vest) terhadap power endurance terjadi karena adanaya adaptasi sel otot, sel saraf, dan metabolisme sel terhadap beban latihan dengan intensitas tinggi yang diberikan. Sejalan dengan kebutuhan power endurance yang harus mempertahankan performa dengan intensitas yang tinggi dalam permainan futsal (Mohammed dkk., 2014). Selain itu, latihan dengan metode interval juga terbukti meningkatkan running economy sejalan dengan adaptasi otot dan metabolisme (García-pinillos dkk., 2017). Yang mana berlari adalah aktivitas dengan proporsi terbesar yang dilakukan atlet saat bermain futsal. Kemudian interval training juga berdampak siginifikan terhadap peningkatan kapasitas kardiovaskular, kekuatan isokinetik otot, respon jantung terhadap beban latihan, power endurance dan peningkatan kecepatan recovery (Cicioni-kolsky dkk., 2013).

Program latihan yang diberikan selama delapan minggu kepada atlet futsal putri Pusaka Angels, selain menggunakan metode interval, juga digunakan rompi beban (weighted vest) untuk menambah efek loading dalam latihan interval tersebut. Penambahan beban latihan menggunakan rompi beban termasuk pada salah satu bentuk latihan resisted training. Menambah tahanan atau beban (berat) ketika atlet melakukan aktivitas latihan. Secara umum tujuan dari resisted training adalah untuk meningkatkan power otot pada tubuh bagian bawah sambil mempertahankan teknik berlari (Cottle dkk., 2014). Penggunaan rompi beban sangat dianjurkan dalam latihan dengan bentuk gerakannya berlari, melompat, dan gerakangerakan eksplosif lainnya tanpa membatasi ruang gerak atlet (Bolger dkk., 2016). Latihan resisted training menggunakan rompi beban terbukti dapat meningkatkan akselerasi (Bachero-Mena \& GonzalezBadillo, 2014).

Berdasarkan pembahasan temuan penelitian di atas, bukan berarti penelitian yang penulis lakukan di sini telah sempurna. Penelitian ini masih memiliki kekurangan dan keterbatasan yang dapat disempurnakan pada penelitian lebih lanjut, demi kepentingan kemajuan ilmu pengetahun dalam olahraga prestasi. Beberapa keterbatasan penelitian ini diantaranya terdapat dalam penggunaan metode ex-post facto. Dengan menggunakan metode ini, penulis hanya mengevaluasi data hasil dari perlakuan yang telah berlalu. Yang mana perlakuan tersebut sebelumnya telah diberikan oleh tim pelatih Pusaka Angel pada bulan Desember, Januari, dan Februari tahun 2020. Sehingga penulis tidak dapat mengontrol dengan leluasa perlakuan yang diberikan dan variabel-variabel lain yang berkemungkinan mempengaruhi hasil tes kemampuan power endurance atlet futsal Pusaka Angels.

Berhubungan dengan penggunaan metode expost facto, penulis juga tidak dapat menentukan dengan leluasa variabel bebas apa yang digunakan untuk mempengaruhi variabel terikat. Variabel bebas berupa latihan metode interval meggunakan rompi beban (weighted vest) merupakan treatment yang diberikan oleh tim pelatih Pusaka Angel secara independen, tanpa dipengaruhi oleh pilihan penulis dalam penelitian 
ini. Karna treatment perlakukan yang diberikan tim pelatih telah berlalu dan telah diberikan. Penulis di sini hanya mengevaluasi seberapa besar pengaruh treatment tersebut terhadap kemampuan power endurance atlet.

Berikutnya kekurangan dari penelitian ini adalah penggunaan desain one group pretest posttest design. Karena pada desain penelitian ini hanya membandingkan hasil tes awal dan tes akhir pada satu kelompok sampel saja (kelompok eksperimen). Tanpa dibandingkan dengan hasil tes awal dan tes akhir dari kelompok lain yang tidak mendapatkan treatment metode interval meggunakan rompi beban (weighted vest) sebagai kelompok kontrol atau kelompok pembanding. Hal ini dikarenakan memang perlakuan dan tes (awal dan akhir) telah berlalu, sehingga penulis tidak dapat mempersiapkan atau mengkondisikan adanya kelompok lain (kelompok kontrol) sebagai pembanding.

\section{Simpulan dan Rekomendasi}

Berdasarkan pembahasan dalam diskusi penelitian dapat disimpulkan bahwa terdapat pengaruh latihan interval dengan menggunakn rompi beban terhadap peningkatan kemampuan power endurance pada atlet futsal putri Pusaka Angel, dimana penelitian ini menunjukkan bahwa kemampuan power endurance atlet futsal putri tim Pusaka Angel mengalami peningkatan yang signifikan dengan latihan metode interval menggunakan rompi beban (weighted vest), para ahli menguatkan temuan hasil pada penelitian ex-post facto ini bahwa kemampuan power endurance atlet futsal putri tim Pusaka Angel mengalami peningkatan yang signifikan dengan latihan metode interval menggunakan rompi beban (weighted vest), meningkatnya kemampuan power endurance atlet berdampak positif terhadap performa atlet di dalam pertandingan. Terbukti dari meningkatnya menit bermain atlet, berkurangnya kesalahan-kesalahan passing yang dapat diintercept oleh lawan, dan kemampuan atlet untuk mempertahankan teknik dalam keadaan lelah.

Beberapa rekomendasi yang dapat disarankan oleh penulis adalah yaitu tim-tim futsal profesional secara umum, dan tim futsal putri Pusaka Angel pada khususnya, untuk menggunakan latihan dengan metode interval menggunakan rompi beban (weighted vest) untuk meningkatkan kemampuan power endurance atlet, selanjutnya penulis juga menyarankan untuk mengeksplorasi lebih jauh manfaat latihan dengan metode interval menggunakan rompi beban (weighted vest), baik terhadap komponen fisik lainnya, atau terhadap psikologis atlet dalam berlatih. Selain itu dapat juga mengembangkan penelitian tersebut pada cabang-cabang olahraga yang lainnya, dan terkahir penulis juga menyarankan pada peneliti selanjutnya untuk mengisi kekurangan dan keterbatasan penelitian ini. Dengan menguji metode interval menggunakan rompi beban (weighted vest) terhadap power endurance menggunakan metode true exsperiment dan desain penelitian yang memiliki kelopok kontrol sebagai pembanding. Agar hasil penelitiannya dapat digeneralisasi secara lebih valid dan dapat dipertanggung jawabkan.

\section{Daftar Pustaka:}

Ayarra, R., Nakamura, F. Y., Iturricastillo, A., Castillo, D., \& Yanci, J. (2018). Differences in Physical Performance According to the Competitive Level in Futsal Player. Journal of Human Kinetics, 64, 275-285. https://doi.org/10.1515/hukin-2017-0201

Bachero-Mena, B., \& Gonzalez-Badillo, J. J. (2014). Effects of Resisted Sprint Training On Acceleration With Three Different Loads Accounting For 5, 12.5, And 20\% Of Body Mass. Journal of Strenght and Conditioning Research, 28(10), 2954-2960. https://doi.org/10.1519/jsc.0000000000000492

Berdejo-del-Freno, D., \& Laupheimer, M. W. (2014). Recovery \& Regeneration Behaviours in Elite English Futsal Players. 2(3), 77-82. https://doi.org/10.12691/ajssm-2-3-2

Bolger, R., Lyons, M., Harrison, A. J., \& Kenny, I. C. (2016). Coaching sprinting: Expert coaches' perception of resistance-based training. International Journal of Sports Science \& Coaching, 0(0), 1-9. https://doi.org/10.1177/1747954116667113 
Buchheit, M., \& Laursen, P. B. (2013). High-Intensity Interval Training, Solutions to the Programming Puzzle. Sports Medicine, 43(10), 927-954. https://doi.org/10.1007/s40279-013-0066-5

Causer, J., \& Ford, P. R. (2014). “ Decisions , decisions , decisions "”: transfer and specificity of decision-making skill between sports. Springer. https://doi.org/10.1007/s10339-014-0598-0

Cicioni-kolsky, D., Lorenzen, C., Williams, M. D., \& Kemp, J. G. (2013). Endurance and sprint benefits of high-intensity an supramaximal interval training. European Journal of Sport Science, 13(3), 304 311. https://doi.org/10.1080/17461391.2011.606844

Clark, K. P., Stearne, D. J., Walts, C. T., \& Miller, A. N. D. (2010). The Longitudinal Effects Of Resisted Sprint Training Using Weighted Sleds Vs.Weighted Vests. Journal of Strenght and Conditioning Research, 24(12), 3287-3295. https://doi.org/10.1519/jsc.0b013e3181b62c0a

Cottle, C. A., Carlson, L. A., \& Lawrence, M. A. (2014). Effects of Sled Towing on Sprint Starts. Journal of Strenght and Conditioning Research, 28(5), 1241-1245. https://doi.org/10.1519/jsc.0000000000000396

DJ, R., JA, R., M, C.-P., \& PE, A. (2016). Physical performance of elite and subelite Spanish female futsal players. Biology of Sport, 33(3), 297-304. https://doi.org/10.5604/20831862.1212633

Dogramaci, S. N., Watsford, M. L., \& Murphy, A. J. (2011). Time-Motion Analysis of International and National Level Futsal. Journal of Strenght and Conditioning Research, 25(3), 646-651. https://doi.org/10.1519/jsc.0b013e3181c6a02e

Fraenkel, jack R., Wallen, N. E., \& Hyun, H. H. (2012). How to Design and Evaluate Research in Education (8th ed.). McGraw-Hill Higher Education.

García-pinillos, F., Soto-hermoso, V. M., \& Latorre-román, P. A. (2017). How does high-intensity intermittent training affect recreational endurance runners ? Acute and chronic adaptations : A systematic review. Journal of Sport and Health Science, 6(1), 54-67. https://doi.org/10.1016/j.jshs.2016.08.010

Gledhill, A., Harwood, C., \& Forsdyke, D. (2017). Psychosocial factors associated with talent development in football: A systematic review. Psychology of Sport and Exercise, 31, 93-112. https://doi.org/10.1016/j.psychsport.2017.04.002

Gratton, C. (2014). Research Method for Sports Studies. https://doi.org/https://doi.org/10.4324/9781315796222

Ismail, S. I., Adnan, R., \& Sulaiman, N. (2014). Moderate Effort Instep Kick in Futsal. Procedia Engineering, 72, 186-191. https://doi.org/10.1016/j.proeng.2014.06.031

John, J., \& Sidik, D. Z. (2017). Pengaruh Metode Repetisi dalam Latihan Plyometrics Single-Leg Speed Hop terhadap Peningkatan Power Endurance Tungkai pada Cabang Olahraga Futsal. Jurnal Kepelatiban Olabraga, 10(2), 1-11.

Lhaksana, J. (2011). Taktik dan Strategi Futsal Modern. Be Champion.

Macadam, P., Simperingham, K. D., \& Cronin, john B. (2016). Acute Kinematic and Kinetic Adaptations to Wearable Resistance During Sprint Acceleration. Journal of Strenght and Conditioning Research, 31(5), 1297-1304. https://doi.org/10.1519/JSC.0000000000001596

MacInnis, M. J., \& Gibala, M. J. (2017). Physiological adaptations to interval training and the role of exercise intensity. Journal of Physiology, 595(9), 2915-2930. https://doi.org/10.1113/JP273196

Mănescu, C. O. (2018). The Principles of Physical Training In Futsal. The Bucharest Universitu of Economic Studies, $X(2), 104-109$.

Milanez, V. F., Pedro, R. E., Moreira, A., Boullosa, D. A., Salle-neto, F., \& Nakamura, F. Y. (2011). The Role of Aerobic Fitness on Session Rating of Perceived Exertion in Futsal Players. International Journal of Sports Physiology and Performance, 6, 358-366. 
https://doi.org/10.1123/ijspp.6.3.358.

Mills, A., Butt, J., Maynard, I., \& Harwood, C. (2012). Identifying factors perceived to influence the development of elite youth football academy players football academy players. Journal of Sports Sciences, 30(15), 1593-1604. https://doi.org/10.1080/02640414.2012.710753

Mohammed, A., Shafizadeh, M., \& Platt, G. K. (2014). Effects of the level of expertise on the physical and technical demands in futsal. International Journal of Performance Analysis in Sport, 14, 473-481. https://doi.org/10.1080/24748668.2014.11868736

Mulyawan, R., Sidik, D. Z., \& Hidayah, N. (2016). Dampak Penerapan Pola Pelatihan Harness Menggunakan Metode Interval dan Repetisi Terhadap Peningkatan Kemampuan Power Endurance Tungkai. Jurnal Sains Keolahragaan Dan Kesehatan, 1(1), 1-7. https://doi.org/http://dx.doi.org/10.5614\%2Fjskk.2016.1.1.1

Naser, N., \& Ali, A. (2016). A descriptive-comparative study of performance characteristics in futsal players of different levels. Journal of Sports Sciences. https://doi.org/10.1080/02640414.2015.1134806

Naser, N., Ali, A., \& Macadam, P. (2017). Journal of Exercise Science \& Fitness Physical and physiological demands of futsal. Journal of Exercise Science \& Fitness, 15(2), 76-80. https://doi.org/10.1016/j.jesf.2017.09.001

Ramac1, S. N. D. O. Ğ., Watsford, M. L., \& Murphy, A. J. (2015). Activity Profile Differences Between Subelite Futsal Teams. 8(2). https://doi.org/dx.doi.org/10.4025/jphyseduc.v29i1.296

Rodrígue-Lorenzo, L., Fernandez-del-Olmo, M., Sanchez-Molina, J. A., \& Martín-Acero, R. (2016). Role of Vertical Jumps and Anthropometric Variables in Maximal Kicking Ball Velocities in Elite Soccer Players. Journal of Human Kinetics, 53, 143-153. https:/ / doi.org/10.1515/hukin-2016-001 18

Rodrigues, V. M., Ramos, G. P., Mendes, T. T., Cabido, C. E. T., Melo, E. S., Condessa, L. A., Coelho, D. B., \& Garcia, E. S. (2011). Intensity of Official Futsal Matches. Journal of Strenght and Conditioning Association, 25(9), 2482-2487. https://doi.org/10.1519/jsc.0b013e3181fb4574

Sappaile, B. I. (2010). Konsep Penelitian Ex-Post Facto. Jurnal Pendidikan Matematika, 1(2), 105-113.

Seiler, S., \& Sjursen, J. E. (2004). Effect of work duration on physiological and rating scale of perceived exertion responses during self-paced interval training. Scandinavian Journal of Medicine \& Science in Sports, 14, 318-325. https://doi.org/10.1046/j.1600-0838.2003.00353.x

Sidik, D. Z. (2010). Pembinaan Kondisi Fisik (Dasar dan Lanjutan). FPOK UPI.

Sidik, D. Z., Pesurnay, P., \& Afari, L. (2019). Pelatiban Kondisi Fisik. PT. Remaja Rosdakarya.

Sugiyono. (2010). Metode Penelitian Pendidikan Pendekatan Kuantitatif, kualitatif, dan R\&D. Alfabeta.

Sugiyono. (2011). Metode Penelitian Kuantitatif, Kualitatif dan ReD. Alfabeta.

Vic, H., \& Engler, L. (2011). Futsal: Technique, Tactics and Training. Meyer And Meyer Sport.

Vicente-vila, P. (2016). The Goalkeeper Influence on Ball Possession Effectiveness in Futsal. 51(June), 217-224. https://doi.org/10.1515/hukin-2015-0185.

Yiannaki, C., Carling, C., \& Collins, D. (2018). Futsal as a potential talent development modality for soccer-a quantitative assessment of high-level soccer coach and player perceptions. Science and Medicine in Football, 2(4), 299-308. https://doi.org/10.1080/24733938.2018.1483079. 